\title{
Treatment of Ventriculitis with Gentamicin and Cloxacillin in Infants Born with Spina Bifida
}

\author{
J. LORBER, S. C. KALHAN, and B. MAHGREFTE^ \\ From the Department of Child Health, University of Sheffield, and the Children's Hospital, Sheffield
}

\begin{abstract}
Lorber, J., Kalhan, S. C., and Mahgrefte, B. (1970). Archives of Disease in Childhood, 45, 178. Treatment of ventriculitis with gentamicin and cloxacillin in infants born with spina bifida. Of 783 newborn infants with spina bifida cystica and cranium bifidum treated in the 6 years to December 1966, 11\% died of ventriculitis. $24 \%$ of all deaths were due to this cause. Experience with treatment of ventriculitis with 2 of the antibiotic drugs, gentamicin and cloxacillin, during an 18-month period is presented. CSF levels were estimated during systemic and intraventricular administration of a drug and the clinical response was correlated with these levels. Of the 14 infants treated with gentamicin, the majority of whom had Gram-negative infections, 7 recovered. The 7 who died as a result of ventriculitis were mostly under 4 weeks of age. There was close correlation between the CSF levels attained and results of therapy. It was essential to give the drug intraventricularly to attain any recordable level, and to obtain the best results the systemic and intraventricular dose of the drug had to be adjusted to give CSF levels that exceeded the minimum inhibitory concentration considerably. 2 infants who recovered died later of other causes, but 4 of the 5 survivors had normal developmental attainments. No toxic effects were observed.
\end{abstract}

The 7 infants treated with cloxacillin, all of whom had Gram-positive infections, survived, 3 with normal development.

The importance of intraventricular administration of drugs and proper control of doses to achieve optimal therapeutic levels is emphasized.

Meningitis, or more correctly ventriculitis, is a major initial hazard to the life of infants born with spina bifida cystica. It remains a hazard even later in life in those whose hydrocephalus is treated with shunt procedures or whose back lesion requires further surgery. For example, Eckstein et al. (1967) reported the results on 1091 patients with either spina bifida or hydrocephalus. There were 373 deaths, and of these $158(42 \%)$ were due to meningitis. 'Meningitis' was by far the most important cause of death, $14 \%$ of all cases. 206 of the 1091 patients had no spina bifida, and though the paper does not state separately the causes of death in those without and those with spina bifida, it may be safely assumed that most deaths due to 'meningitis' occured in the 885 spina bifida subjects. In 58 subjects the cause of death was not known.

Received 29 July 1969

*Present address: Health Department, National Iranian Steel Factory, Esfahan, Iran.
These data indicate that roughly $20 \%$ of their spinim bifida patients died of 'meningitis' and that about half of all deaths were due to this cause. Most of these deaths occurred in the first year of life.

In our own unit we admitted 783 newbor infants with spina bifida or cranium bifidum during the 6 years from January 1961 to December 196\% Up to the end of 1968, 353 died (45\%), 85 (11\%) 팡 all cases died of ventriculitis, and $24 \%$ of all deaths. were due to this cause. There was a decrease the number of deaths due to ventriculitis during these years. Among 372 babies admitted in 19610 $63,53(14 \%)$ died of ventriculitis as compared with $32(8 \%)$ out of 411 admitted in 1964-6\% Most deaths due to ventriculitis occurred early infancy, but some occurred later when the ventro culitis was usually a complication of the shunting procedures. In 1961-63 there were 39 deaths due to neonatal ventriculitis $(10.5 \%)$ and in 1964 常 66 these numbers fell to 26 or $6.3 \%$ (Table I). 
TABLE I

Deaths Due to Ventriculitis in Spina Bifida and Cranium Bifidum (1961-1966)

\begin{tabular}{|c|c|c|c|c|c|c|c|c|c|c|c|}
\hline \multirow{3}{*}{ Year } & \multirow{3}{*}{$\begin{array}{c}\text { No. } \\
\text { Admitted }\end{array}$} & \multirow{2}{*}{\multicolumn{2}{|c|}{ Died }} & \multicolumn{6}{|c|}{ Died of Ventriculitis } & \multirow{2}{*}{\multicolumn{2}{|c|}{$\begin{array}{c}\text { Died } \\
\text { of } \\
\text { Other Causes }\end{array}$}} \\
\hline & & & & \multicolumn{2}{|c|}{ Early } & \multicolumn{2}{|c|}{ Late } & \multicolumn{2}{|c|}{ Total } & & \\
\hline & & Nou & $/ 0$ & No. & $\%$ & No. & $\%$ & No. & $\%$ & No. & $\%$ \\
\hline $\begin{array}{l}1961-1963 \\
1964-1966\end{array}$ & $\begin{array}{l}372 \\
411\end{array}$ & $\begin{array}{l}198 \\
155\end{array}$ & $\begin{array}{l}53 \cdot 0 \\
37 \cdot 7\end{array}$ & $\begin{array}{l}39 \\
26\end{array}$ & $\begin{array}{r}10 \cdot 5 \\
6 \cdot 3\end{array}$ & $\begin{array}{r}14 \\
6\end{array}$ & $\begin{array}{l}3 \cdot 7 \\
1 \cdot 4\end{array}$ & $\begin{array}{l}53 \\
32\end{array}$ & $\begin{array}{r}14 \cdot 0 \\
7 \cdot 7\end{array}$ & $\begin{array}{l}145 \\
123\end{array}$ & $\begin{array}{l}38 \cdot 9 \\
29 \cdot 9\end{array}$ \\
\hline $1961-1966$ & 783 & 353 & $45 \cdot 0$ & 65 & $8 \cdot 3$ & 20 & $2 \cdot 5$ & 85 & $10 \cdot 8$ & 268 & $34 \cdot 2$ \\
\hline
\end{tabular}

Some of the deaths from ventriculitis occurred suddenly and the diagnosis was first made at necropsy. Nevertheless, we made great efforts to diagnose ventriculitis early and instituted appropriate antibiotic therapy, as indicated by bacterial sensitivity tests. Even so, in the earlier years of our experience relatively few babies recovered from this complication. The early closure of the spina bifida wound has not altered the incidence of ventriculitis to a significant extent (Sharrard at al., 1963), and in our experience ventriculitis still occurs in some $10-20 \%$ of all cases (Lorber and Segall, 1962; Lorber and Bruce, 1963). Controlled trials, using different drugs for antibiotic prophylaxis during and after surgical treatment of the spina bifida has not diminished the incidence of ventriculitis (Lorber and Bruce, 1963). Since this was established, we have not used antibiotic drugs to prevent ventriculitis in the newborn.

Ventriculitis and meningitis are particularly dangerous in these infants for 4 reasons.

(1) Meningitis and ventriculitis are generally more dangerous in the newborn and in young infants, and carry a high mortality, even in anatomically normal babies (Fosson and Fine, 1968). Hydrocephalus often develops in those who recover (Lorber and Pickering, 1966).

(2) In infants with spina bifida the cause of the ventriculitis is usually an infected back wound, with pus tracking up along the spinal canal towards the brain and the ventricles. These sources of infection often persist and may reinfect the ventricles even during treatment. This factor is a common reason for failure.

(3) Most infants with spina bifida already have hydrocephalus before the onset of the ventriculitis (Lorber, 1961). For this reason it is practically impossible to achieve an adequate antibiotic concentration in the CSF by systemic administration of any drug, as is being shown in our current trial. Further, infants with hydrocephalus are often treated by shunt procedures that predispose to ventriculitis.

(4) The organisms responsible for the ventriculitis are often those not susceptible to the commonly used antibiotic drugs. These organisms include many strains of Esch. coli as well as proteus and Ps. pyocyaneus (Lorber and Segall, 1962; Lorber and Bruce, 1963).

The prognosis of Gram-negative infections was particularly unfavourable. In a consecutive series, 33 cases of ventriculitis occurred among 262 infants born with spina bifida (12\%). Gram-negative organisms were responsible in 22 cases and 18 died, while out of 11 with Gram-positive organisms, 6 died. Only 2 survivors had an intelligence quotient of 90 or more at 1 year of age (Lorber and Segall, 1962).

More recently, several new antibiotic drugs have become available for the treatment of both Gramnegative and Gram-positive infections, with promise of better results. Cases have been treated with kanamycin (Lorber, 1967), colistin, gentamicin, (Newman and Holt, 1967) ampicillin, cloxacillin, and cephaloridine. So far, we have found gentamicin and cloxacillin particularly effective against organisms sensitive to one of these drugs. We here describe our experience with these 2 drugs in the treatment of 21 infants with ventriculitis.

\section{Present Investigation}

Case material. The case material of this study consists of 21 infants. Nineteen were admitted between July 1967 and January 1969. They developed ventriculitis due to organisms that were sensitive to either gentamicin or cloxacillin.

During the same period 20 other cases of ventriculitis occurred which were due to a variety of organisms and were treated by other drugs. Of these, 9 survived, 6 recovered from their ventriculitis but died later of other causes, and 5 died as a direct result of their ventriculitis. They will not be considered further.

Of the 21 patients now being reported, 14 were 
treated with gentamicin and 7 with cloxacillin; among the latter group 2 were admitted earlier in 1967.

Diagnostic criteria. In 19 cases the diagnosis of ventriculitis was made on the basis of positive culture from the ventricular CSF. In one other case Grampositive cocci were seen in the deposit, together with pleocytosis, high protein, and low CSF glucose levels. In the remaining infant there was pleocytosis in the CSF, and blood culture was positive for Staphylococcus albus.

Choice of antibiotic therapy. During the period under review our practice was, on finding a turbid CSF at the time of a diagnostic ventricular puncture, to start therapy with intramuscular and intraventricular chloramphenicol, so that there should be no delay in initiating therapy with a broad spectrum drug. This was given until we knew the identity and the sensitivity pattern of the organism. A change was made, (a) if the organism was not sensitive to chloramphenicol, or (b) if a less toxic drug could be used, or later, (c) in case of failure to obtain sterilization of the CSF.

In other instances the infant was already on antibiotic therapy for the treatment of wound infection before the diagnosis of ventriculitis. It was assumed that the organism responsible for the ventriculitis was the same that caused the wound infection. Hence, the same drug therapy was continued with the addition of intraventricular injections, unless new bacteriological evidence indicated the need for a change.

Only one antibiotic was used at any one time.

\section{Bacteriological data.}

(a) 14 infants treated with gentamicin (Table II). Six different organisms were isolated from the CSF in these 14 infants. Esch. coli was the commonest (6 infections), followed by Proteus species (3), Ps. pyocyaneus (2), and Streptococcus faecalis, a coliform organism (Actinobacter anitratus), and Mycoplasma pneumoniae (one each). There were no double infections. All

\section{TABLE II}

16 Infants with Ventriculitis Treated with Gentamicin: Results Related to Organism

\begin{tabular}{|c|c|c|c|c|c|}
\hline \multirow{2}{*}{ Organism } & \multirow{2}{*}{$\begin{array}{l}\text { Total } \\
\text { Cases }\end{array}$} & \multicolumn{3}{|c|}{ Recovered } & \multirow{2}{*}{$\begin{array}{c}\text { Died } \\
\text { of } \\
\text { Ventri- } \\
\text { culitis }\end{array}$} \\
\hline & & Normal* & Retarded & $\begin{array}{l}\text { Died Later } \\
\text { of Other } \\
\text { Causes }\end{array}$ & \\
\hline $\begin{array}{l}\text { Strep. faecalis } \\
\text { Esch. coli } \\
\text { Coliform } \\
\text { Proteus } \\
\text { Ps. pyocyaneus } \\
\text { Mycoplasma } \\
\quad \text { pneumoniae }\end{array}$ & $\begin{array}{l}1 \\
6 \\
1 \\
3 \\
2 \\
1\end{array}$ & $\begin{array}{l}\frac{1}{2} \\
\frac{1}{-}\end{array}$ & $\begin{array}{l}\overline{1} \\
\overline{-}\end{array}$ & $\begin{array}{l}\overline{1} \\
\overline{-}\end{array}$ & $\begin{array}{l}- \\
3 \\
1 \\
1 \\
2 \\
-\end{array}$ \\
\hline Total & 14 & 4 & 1 & 2 & 7 \\
\hline
\end{tabular}

^Excluding physical handicaps resulting from the myelomeningocele. these organisms were sensitive in vitro to gentamicin at the beginning of treatment, and no organism became. resistant even in failed cases.

The minimum inhibitory concentration (MIC) of the drug against the organisms ranged from $0.8 \mu \mathrm{g} . / \mathrm{ml}$ 은 to $1.6 \mu \mathrm{g} . / \mathrm{ml}$. The MIC remained the same throughoue therapy in those whose culture remained positive.

(b) 7 infants treated with cloxacillin (Table III). Aln़ these had infections by Gram-positive organisms Staphylococcus albus was responsible in 3 cases (alf associated with shunt treatment of hydrocephalus) $\vec{D}$ Staphylococcus aureus was grown in 2 cases, and in onethis was associated with a $\beta$-haemolytic streptococcus $\vec{\omega}$ (the only double infection in the series), Streptococcus viridans was grown in one, and in one Gram-positiveñ cocci were seen in the deposit but the culture was sterile.

\section{TABLE III}

7 Infants with Ventriculitis Treated with Cloxacillin Results Related to Organism

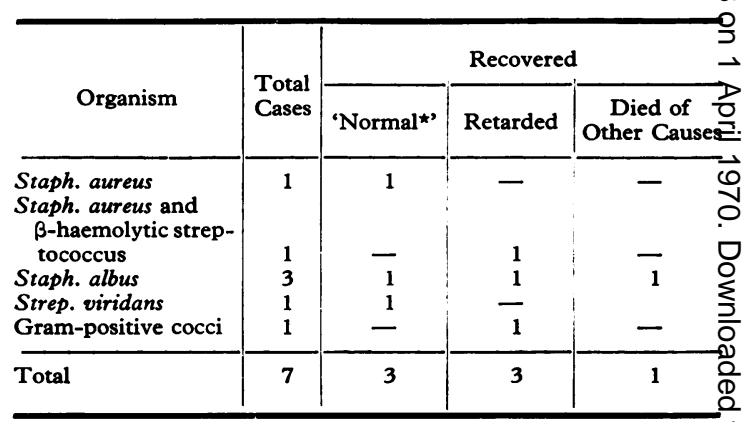

«Excluding physical handicaps resulting from the myelomeningocele $\overline{\bar{\sigma}}$

The MICs were not obtained in the cloxacillin-? treated cases, but the known levels vary between $0 \cdot 1$ चै $0.25 \mu \mathrm{g} . / \mathrm{ml}$. (Knudsen, Brown, and Rolinson, 1962)

CSF concentration of gentamicin and of cloxa $\frac{\text { ? }}{0}$ cillin (Tables IV and V). CSF assays of drug levelswere carried out: (a) Either during intramuscula therapy, preceding the first intraventricular dose (3 estimations in gentamicin-treated and 5 in cloxacillin treated infants); none of these yielded levels reaching the level of the MIC of the drug. (b) During combined intramuscular and intraventricular therapy. 137 estio mations were carried out on samples taken 24 hours. after intraventricular injection, immediately before thes next dose. (For techniques of estimations seథu Appendix.)

Drug therapy. The dose of gentamicin given by intramuscular injection was gradually increased fromo patient to patient according to experience gained The range was from $0.5 \mathrm{mg}$. $/ \mathrm{kg}$. to $8 \mathrm{mg} . / \mathrm{kg}$. daily, in two divided doses (Table IV).

The intraventricular dose of gentamicin was als $\omega^{\circ}$ increased from one $0.5 \mathrm{mg}$. dose daily in 2 cases to $4 \mathrm{mg}$. in 2 others, and $8 \mathrm{mg}$. a day in the remaining $10 \stackrel{\mathrm{D}}{\mathrm{Q}}$ 
TABLE IV

CSF Levels of Gentamicin in Relation to Dosage

\begin{tabular}{|c|c|c|c|c|}
\hline \multicolumn{2}{|c|}{ Dose } & \multirow{2}{*}{$\begin{array}{c}\text { Mean CSF } \\
\text { Levels } \\
(\mu \mathrm{g} . / \mathrm{ml} .)\end{array}$} & \multirow{2}{*}{$\begin{array}{l}\text { No. } \\
\text { of } \\
\text { Cases }\end{array}$} & \multirow{2}{*}{$\begin{array}{l}\text { No. } \\
\text { of } \\
\text { Assays }\end{array}$} \\
\hline $\begin{array}{c}\text { Intramuscular } \\
\text { (mg./kg. } \\
\text { per day) }\end{array}$ & $\begin{array}{c}\text { Intra- } \\
\text { ventricular } \\
\text { (mg./day) }\end{array}$ & & & \\
\hline $\begin{array}{l}0 \cdot 5 \\
2 \cdot 0 \\
4 \cdot 0 \\
4 \cdot 0 \\
6 \cdot 0 \\
6 \cdot 0 \\
8 \cdot 0 \\
8 \cdot 0 \\
8 \cdot 0 \\
8 \cdot 0\end{array}$ & $\begin{array}{l}0 \cdot 5 \\
0.5 \\
4 \cdot 0 \\
8 \cdot 0 \\
\overline{8 \cdot 0} \\
\overline{4 \cdot 0} \\
8 \cdot 0 \\
8 \cdot 0\end{array}$ & $\begin{array}{l}0 \cdot 5 \\
0 \cdot 5 \\
30 \\
27 \cdot 5 \\
<1 \cdot 0 \\
80 \\
<1 \cdot 0 \\
43 \\
4 \cdot 0 \\
57 \cdot 5\end{array}$ & $\begin{array}{l}1 \\
1 \\
1 \\
2 \\
1 \\
3 \\
2 \\
1 \\
3 \\
2\end{array}$ & $\begin{array}{r}4 \\
1 \\
5 \\
9 \\
1 \\
23 \\
2 \\
7 \\
37 \\
12\end{array}$ \\
\hline
\end{tabular}

TABLE V

CSF Levels of Cloxacillin in Relation to Dosage

\begin{tabular}{|c|c|c|c|c|}
\hline \multicolumn{2}{|c|}{ Dose } & \multirow{2}{*}{$\begin{array}{c}\text { Mean CSF } \\
\text { Levels } \\
(\mu \cdot g . / m l .)\end{array}$} & \multirow{2}{*}{$\begin{array}{c}\text { No. } \\
\text { of } \\
\text { Cases }\end{array}$} & \multirow{2}{*}{$\begin{array}{c}\text { No. } \\
\text { of } \\
\text { Assays }\end{array}$} \\
\hline $\begin{array}{l}\text { Intramuscular } \\
\text { (mg./day) }\end{array}$ & $\begin{array}{c}\text { Intra- } \\
\text { ventricular } \\
\text { (mg./day) }\end{array}$ & & & \\
\hline $\begin{array}{r}120^{\star} \\
1000^{\star}\end{array}$ & - & $\begin{array}{l}<0.5 \\
<1.5\end{array}$ & $\begin{array}{l}1 \\
2\end{array}$ & $\begin{array}{l}2 \\
3\end{array}$ \\
\hline $\begin{array}{l}250 \\
120-1000 \\
250-1000\end{array}$ & $\begin{array}{r}5 \\
10 \\
20\end{array}$ & $\begin{array}{r}4 \cdot 6 \\
26 \cdot 5 \\
28 \cdot 2\end{array}$ & $\begin{array}{l}1 \\
3 \\
3\end{array}$ & $\begin{array}{r}6 \\
17 \\
8\end{array}$ \\
\hline
\end{tabular}

*Before onset of ventriculitis and of intraventricular treatment.

The intramuscular dose of cloxacillin was $62 \cdot 5-250$ mg. four times daily, according to body weight. The intraventricular dose was $5-20 \mathrm{mg}$. (Table V) and was related to the size of the infant's ventricles.

The duration of intraventricular therapy by either drug was determined by the results of CSF culture. Therapy was discontinued after 3 negative cultures had been obtained. This meant a minimum of 6 and a maximum of 10 injections after the first negative culture, because it took several days' incubation before a culture was finally pronounced sterile. In unsuccessful cases treatment was carried on either until death or until change to a different drug. In successful cases the maximum number of intraventricular injections was 11 with gentamicin and 10 with cloxacillin.

Systemic therapy with gentamicin was usually continued for several days beyond the last intraventricular injection, the longest course being 22 days. Patients on cloxacillin were often treated longer, because of infection of the shunt and other complications requiring operative procedures consisting of revision, removal, or reinsertion of shunts that were colonized by the organisms. The longest course was 6 weeks.

We observed no immediate untoward reactions to either drug.

\section{Results}

\section{(a) Gentamicin-treated cases}

Over-all results. Of the 14 infants treated with gentamicin, 7 died from the ventriculitis, 2 died later of other causes, and 5 are alive. The period of follow-up from the date of diagnosis is between 6 to 19 months, and the oldest survivor is 21 months of age.

Of the 5 survivors one is retarded. He was the oldest child in the series, and his early milestones before the onset of the ventriculitis were already much delayed, due to an earlier episode of ventriculitis and ineffective control of his hydrocephalus.

The other 4 survivors have no apparent sequelae attributable to the ventriculitis.

Case 1. An example is a baby girl whose large thoracolumbar meningomyelocele was repaired at 11 hours of age. The back wound was infected. At the age of 3 weeks she developed ventriculitis. This was diagnosed early when the ventricular CSF showed 22 WBC/cu.mm., with protein of $40 \mathrm{mg} . / 100 \mathrm{ml}$. and sugar $45 \mathrm{mg} . / 100 \mathrm{ml}$. and a heavy pure growth of Streptococcus faecalis. She was first treated with cloxacillin and penicillin (in view of the cultures obtained from the back wound). After 36 hours the organism was found to be resistant to these drugs and treatment was changed to gentamicin. The MIC of gentamicin for Streptococcus faecalis was $1.6 \mu \mathrm{g} . / \mathrm{ml}$. $8 \mathrm{mg}$. gentamicin were injected into the ventricles daily for the next 8 days along with systemic injections of $6 \mathrm{mg} . / \mathrm{kg}$. per day divided in two doses. She also had a cystic swelling containing infected fluid over the spina bifida site, and this was treated with local injections of $4 \mathrm{mg}$. gentamicin for 6 days. CSF levels of gentamicin 24 hours after intraventricular injection ranged from $17-70 \mu \mathrm{g} . / \mathrm{ml}$. (average $43 \mu \mathrm{g} . / \mathrm{ml}$.). The CSF became sterile within 4 days and the cell count returned to normal. Systemic therapy was stopped after 10 days. A ventriculo-caval shunt was carried out at 4 weeks of age.

At 6 months of age she was in excellent health, with good control of her hydrocephalus, and had normal early milestones of development.

A second example of a good result is presented. This case is unusual because she already had a shunt at the time she developed ventriculitis, yet she was cured without removal of the shunt which did not become permanently colonized.

Case 2. Her thoracolumbar meningomyelocele was repaired on the day of her birth. Her back wound became infected. This delayed the surgical treatment of her hydrocephalus until she was 4 weeks old. The shunt had to be revised 18 days later because of blockage. Two days after revision she developed fever, became ill, and started vomiting. Blood culture grew a proteus species. She was treated with systemic 
chloramphenicol, but 3 days later she again became ill with fever, and the CSF showed $200 \mathrm{WBC} / \mathrm{cu} . \mathrm{mm}$., a protein of $600 \mathrm{mg} . / 100 \mathrm{ml}$., and proteus species was grown. As the organism was resistant to chloramphenicol, treatment was changed to gentamicin $8 \mathrm{mg} . / \mathrm{kg}$. per day systemically and $4 \mathrm{mg}$. twice daily intraventricularly. The CSF became sterile after the first injection. The intraventricular injections were continued for 11 days to prevent colonization of the shunt, and systemic therapy was continued for 22 days, till 3 consecutively negative blood cultures had been obtained.

At 18 months she was in excellent health. Her motor and intellectual development was only mildly retarded. Her head circumference of $45 \mathrm{~cm}$. was below the 10th centile.

It is of interest that the levels of gentamicin in the CSF were only $2-8 \mu \mathrm{g} . / \mathrm{ml}$. This may be explained by the fact that she had a shunt in position which drained the CSF freely. It is also of interest that her shunt did not become colonized, presumably because of the constant flow of gentamicin through the system.

(b) Cloxacillin-treated cases (Table III). All 7 infants treated with cloxacillin recovered from the ventriculitis, but one died later from a second episode of ventriculitis. The organism in the first instance was Staphylococcus albus and on the second occasion it was a pyocyaneus. The second episode was treated with chloramphenicol.

In three children complete recovery without sequelae was obtained.

The other three survivors are severely retarded as a result of the ventriculitis.

Age of onset, causative organism, and CSF drug levels. In the cloxacillin-treated cases, it is impossible to assess the prognostic importance of the age at onset, the causative organism, or CSF cloxacillin levels, partly because the results were relatively uniform and partly because there are too few cases for such detailed analysis (Tables III, V, and VII).

Cases treated with gentamicin are analysed in more detail.

(a) Age of onset. As might be expected, the youngest infants fared worst (Table VIII). 9 infants were under 4 weeks of age. 6 died as a direct result of their ventriculitis. An example is an infant who was not considered to be ill when the CSF was examined on the fifth day of his life before proposed shunt procedure. The CSF was teeming with Gram-negative bacilli (Esch. coli.). In spite of this early diagnosis, she died 24 hours after the first dose of gentamicin.

One infant died 3 months after recovery from his ventriculitis.
TABLE VI

Ventriculitis Treated with Gentamicin: Results $\overrightarrow{\overrightarrow{\vec{H}}}$ Related to Age of Onset

\begin{tabular}{|c|c|c|c|c|c|}
\hline $\begin{array}{l}\text { Age } \\
\text { at } \\
\text { Onset } \\
\text { (days) }\end{array}$ & All & Normal* & $\begin{array}{c}\text { Recovered } \\
\text { but } \\
\text { Retarded }\end{array}$ & $\begin{array}{c}\text { Died } \\
\text { Later } \\
\text { of Other } \\
\text { Causes }\end{array}$ & $\begin{array}{c}\text { Died } \\
\text { of } \\
\text { Ventri- } \\
\text { culitis }\end{array}$ \\
\hline $\begin{array}{l}\text { Up to } 14 \\
14-28 \\
28+\end{array}$ & $\begin{array}{l}6 \\
3 \\
5\end{array}$ & $\begin{array}{l}1 \\
1 \\
2\end{array}$ & $\frac{-}{1}$ & $\frac{1}{1}$ & $\begin{array}{l}4 \\
2 \\
1\end{array}$ \\
\hline Total & 14 & 4 & 1 & 2 & 7 \\
\hline
\end{tabular}

*Excluding physical handicaps resulting from the myelomeningocele.

\section{TABLE VII}

14 Infants with Ventriculitis Treated with Gentamicin: Results Related to CSF Concentration of Gentamicin $\vec{V}$ (MIC of All Organisms was 0.8-1.5 $\mathrm{g} . / \mathrm{ml}$.)

\begin{tabular}{|c|c|c|c|c|c|c|}
\hline \multicolumn{3}{|c|}{$\begin{array}{c}\text { Average CSF Levels } \\
(\mu \mathrm{g} . / \mathrm{ml} .) \\
(101 \text { estimations })\end{array}$} & \multicolumn{2}{|c|}{ Recovered } & \multicolumn{2}{|c|}{ Died } \\
\hline \multicolumn{3}{|c|}{$\begin{array}{l}\text { Up to } 2 \\
4-6 \\
30 \\
43-130\end{array}$} & \multicolumn{2}{|c|}{$\begin{array}{l}-1^{\star} \\
1 \\
5\end{array}$} & \multicolumn{2}{|c|}{$\begin{array}{l}3 \\
2 \\
1 \\
1\end{array}$} \\
\hline \multicolumn{7}{|c|}{ TABLE VII } \\
\hline \multirow{2}{*}{$\begin{array}{c}\text { Age } \\
\text { at Onset } \\
\text { (wk.) }\end{array}$} & \multirow[b]{2}{*}{ All } & \multicolumn{5}{|c|}{ Recovered } \\
\hline & & & Jormal* & & arded & $\begin{array}{l}\text { Died } \\
\text { of Other } \\
\text { Causes }\end{array}$ \\
\hline $\begin{array}{l}2-4 \\
>4(5-17)\end{array}$ & $\begin{array}{l}3 \\
4\end{array}$ & & $\begin{array}{l}2 \\
1\end{array}$ & & $\overline{3}$ & 1 \\
\hline Total & 7 & & 3 & & 3 & 1 \\
\hline
\end{tabular}

^Excluding handicaps resulting from the myelomeningocele.

Case 3. His thoracolumbar meningomyelocele was $N$ repaired at the age of 7 hours. At the age of 6 days he developed fever, irritability, and vomiting. His $\mathrm{O}$ ventricular CSF contained $349 \mathrm{WBC} / \mathrm{cu} . \mathrm{mm}$., protein $\mathrm{N}$ $70 \mathrm{mg} . / 100 \mathrm{ml}$., and glucose less than $5 \mathrm{mg} / 100 \mathrm{ml}$. There were large numbers of Gram-negative bacilli on the smear, which on culture were found to be Esch. coli. Blood culture also grew Esch. coli. First he was given \& chloramphenicol, but when the organism was found to be resistant to it and sensitive to $0.8 \mu \mathrm{g} . / \mathrm{ml}$. of genta- $T$ micin, treatment was changed to gentamicin after 1 day, $\frac{\vec{D}}{\Phi}$ with $6 \mathrm{mg} . / \mathrm{kg}$. per day intramuscularly and daily $\stackrel{\rho}{\square}$ intraventricular injections of $8 \mathrm{mg}$. It took 7 days for 
the CSF to become sterile in spite of very high gentamicin levels, which exceeded $100 \mu \mathrm{g} . / \mathrm{ml}$. during the first week. Intraventricular injections were given for 14 days and intramuscular therapy for 20 days. Subsequently all ventricular CSF samples remained normal, including those taken during his last fatal illness.

$\mathrm{He}$ died 3 months after recovery from ventriculitis, having suffered first from gastro-enteritis due to type specific Esch. coli. (O127) followed by staphylococcal septicaemia.

Only 2 infants survive who were under 28 days of age at the time of diagnosis.

Case 4. A large lumbosacral myelomeningocele was repaired on the day of birth. On the 12th postoperative day she became febrile and irritable. Her back wound had become tense and bulging. $10 \mathrm{ml}$. yellow turbid CSF were aspirated from it, which on culture grew a pure growth of proteus. The ventricular $\mathrm{CSF}$ at this stage contained $440 \mathrm{WBC} / \mathrm{cu} . \mathrm{mm}$., protein $300 \mathrm{mg} . / 100 \mathrm{ml}$., and sugar $23 \mathrm{mg} . / 100 \mathrm{ml}$. She was treated with intramuscular and intraventricular chloramphenicol for the first two days, and then treatment was changed after the sensitivity results became available. She was given gentamicin $4 \mathrm{mg} . / \mathrm{kg}$. per day intramuscularly, and $8 \mathrm{mg}$. daily intraventricularly. $4 \mathrm{mg}$. daily were also injected into the lumbar sac. Her 24-hour residual ventricular CSF levels of gentamicin ranged from 41-93.4 $\mu \mathrm{g} . / \mathrm{ml}$., and in the lumbar sac ranged from $8 \cdot 5-19 \cdot 1 \mu \mathrm{g} . / \mathrm{ml}$. There was a satisfactory response to this therapy resulting in complete recovery in 17 days.

She did not require a shunt procedure. At 6 months she was well, with normal development of her early milestones.

Older infants fared better. 4 of the 5 over 28 days of age survived this illness, but later one died suddenly at home.

(b) Causative organism. It is difficult to draw conclusions about the importance of the causative organisms, because not enough cases are available for analysis, there being six different organisms responsible for the infections (Table II). Of the 6 infants infected with Esch. coli, 3 died of ventriculitis and only 1 survived without sequelae. All 3 who died were under 2 weeks of age.

It is of interest that 2 out of 3 with proteus infections recovered without sequelae (Cases 2 and 4). The fact that both infants with Ps. pyocyaneus infections died does not necessarily indicate that today the prognosis of ventriculitis due to this organism need be poor. Both of these were treated with too low a dosage of gentamicin to achieve good CSF levels, and there were other adverse factors present as well, including delayed diagnosis and extreme hydrocephalus in both cases (see Addendum). (c) CSF levels (Tables IV and VII, and Fig. 1). By far the most important factor in prognosis was the level of the drug in the CSF. This level was closely linked to the intraventricular dose. Out of 8 infants whose average CSF gentamicin levels were $30 \mu \mathrm{g} . / \mathrm{ml}$. or more, 6 survived (Table VII and Fig. 1). In contrast, only 1 infant survived out of 6 whose average level did not exceed $6 \mu \mathrm{g} . / \mathrm{ml}$. The only child in this group who survived had a ventriculocaval shunt and was the only gentamicintreated infant who did not have a 'closed system' (Case 2).

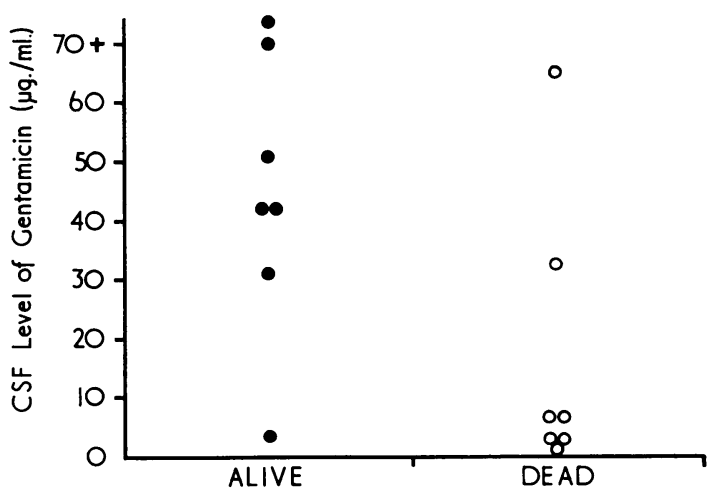

FIG. 1.-Mortality related to CSF level of gentamicin.

Two infants died in spite of high CSF levels of gentamicin. In both there were purulent lesions in the central nervous system in addition to the ventriculitis. In one of these the ventriculitis was under control when she died.

Case 5. This child was born with a sacral myelomeningocele which was repaired at the age of 8 hours. On the 12th postoperative day she developed fever with general deterioration on her condition. Her urine was found to be infected with a proteus which was treated with ampicillin. Blood cultures were taken which later also grew proteus. Ventricular tap the following day showed $100 \mathrm{WBC} / \mathrm{cu} . \mathrm{mm}$., protein $100 \mathrm{mg} . / 100 \mathrm{ml}$., and on culture grew proteus. She was put on intraventricular and intramuscular chloramphenicol with good response over the next 8 days.

Two days after stopping chloramphenicol she became ill again, her CSF cell count increased, and again pure growth of proteus was present on culture which by now had become resistant to chloramphenicol. It was sensitive to gentamicin. She was treated with intraventricular gentamicin ( $8 \mathrm{mg} . / \mathrm{kg}$. per day) and with intraventricular doses of $8 \mathrm{mg}$. daily with good response. CSF levels of gentamicin ranged from 6-101 $\mu \mathrm{g} . / \mathrm{ml}$. CSF became sterile in three days. The cell count and the protein level returned to almost 
normal levels before intraventricular and later intramuscular therapy was stopped after 12 days. 3 days later she suddenly became ill and died. At necropsy a large intracerebral abscess was found.

CSF levels tended to rise progressively as long as intraventricular therapy was given. This observation suggests that in the later stages of therapy alternate daily injections might have been enough. A typical example is shown in Fig. 2.

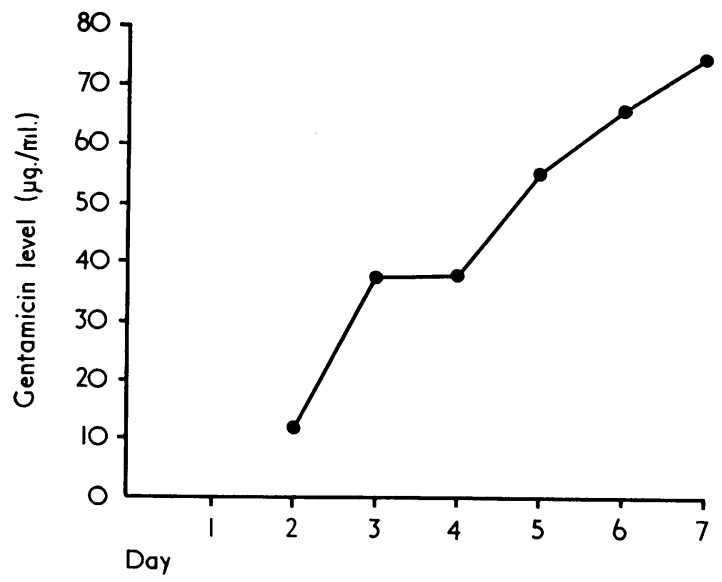

FIG. 2.-24-hour residual CSF level of gentamicin in a case treated with gentamicin by intramuscular $(8 \mathrm{mg} . / \mathrm{kg}$. per day) and intraventricular ( $8 \mathrm{mg}$. per day) routes.

\section{Discussion}

The results of therapy of meningitis and ventriculitis have been disappointing even in anatomically normal infants, particularly in the neonatal period. Ventriculitis still carries a high mortality rate in infancy, in spite of the progressively widening choice of antibiotic drugs. Fosson and Fine (1968) collected the results of treatment in 236 cases from 12 series including their own. None of these included cases with congenital anomalies of the central nervous system. $157(66 \%)$ are known to have died. The results are likely to be less favourable in those with spina bifida cystica and hydrocephalus for reasons already mentioned in the introduction. The results of ventriculitis associated with spina bifida are not easy to ascertain from the published reports. No publications are known to us in which a series of unselected consecutive cases of spina bifida cystica treated from the first day of life are described. Jasper and Merrill (1965) reported 33 patients with meningomyelocele and ventriculitis. Most of these patients were older at the time of diagnosis. The majority of the causative organisms were staphylococci in patients who were treated with ventriculo-atrial shunts. They noted, however, the high mortality associated with Gram-negative infections. Stark (1968) $\stackrel{\rho}{\mathcal{S}}$ reported on 10 cases of ventriculitis in hydrocephalic infants, 9 of these were due to Gram-positive $\Rightarrow$ organisms (staphylococci) and were clearly related $\stackrel{\mathcal{O}^{\circ}}{+}$ to the treatment of hydrocephalus. There was? only one infant whose infection was directly related $\frac{\overline{-}}{6}$ to meningomyelocele. This was an Esch. coli $\frac{\sqrt{\sigma}}{\bar{\phi}}$ infection.

We have already referred to our own earlier ${ }_{\infty}$ experience. In the present study we dealt with an $\overrightarrow{0}$ unselected consecutive series of infants whom we? treated from the first day of life. We have selected $\vec{\omega}$ those patients for discussion who were treated $\stackrel{\rho}{\circ}$ with two of the recently introduced antibiotic drugs. The most important factor in achieving successful results was to obtain an antibiotic drug level in the $\mathrm{O}$ CSF which even 24 hours after the last intra- + ventricular injection exceeded manyfold the mini- mum inhibitory concentration. Our results with $\infty$ gentamicin could have been better had we usedo larger doses in our earlier cases, though occasionally smaller doses may be sufficient to achieve recovery $\rightarrow$ (Newman and Holt, 1967). Nevertheless half our babies recovered from ventriculitis, which can be $\vec{\theta}$ considered satisfactory by any standards. Our $\vec{\theta}$ cloxacillin-treated cases fared better because we. were dealing with Gram-positive infections. The fact that all 7 of the cloxacillin-treated cases survived is an indication of the efficacy of this drug when used by the systemic and intraventricular route in the right type of case. Though our $\mathbb{Q}$ purpose was to report only these two groups of $\overrightarrow{\overrightarrow{0}}$ babies, this does not mean that our other cases of 3 ventriculitis (treated by other, usually longer $F$ established drugs) fared worse. 15 out of 20 . survived the ventriculitis. It is important to note that all our gentamicin-treated cases had a trial of treatment with one or two other antibiotic drugs $\frac{0}{7}$ before failure to respond made us change over to . gentamicin. In spite of this delay and the facto that suboptimal doses were used in our earlier cases, we obtained fair success in the treatment of $ᄋ$ infections due to Gram-positive organisms. For $>$ this reason we now consider that gentamicin may be을. the initial drug of choice in infections caused by N Gram-negative organisms.

Similarly, cloxacillin could be considered as the ${ }^{N}$ first drug of choice in dealing with staphylococcal $\omega$ infections, because of the high recovery rate in our own series and in Stark's (1968) series. The totake absence of toxicity and the non-development of drug resistance are added advantages.

In cases of ventriculitis associated with hydro- $-\frac{7}{0}$ cephalus there is need for combined systemic $\frac{\text { }}{\mathbb{1}}$ and intraventricular therapy, because without $\frac{\stackrel{\odot}{\mathscr{Q}}}{\circ}$ 
intraventricular therapy, therapeutic CSF levels cannot be expected. It is not enough to know the sensitivity of the organism without knowing the MIC; knowing this one can aim at the appropriate drug level in the CSF, and one can determine for each patient individually the dose required to achieve this. The estimation of the drug levels duri.ng therapy and adjustment of the dose to reach therapeutic levels is an important measure in obtaining optimal results.

As a result of using these techniques the over-all results of treatment among 39 consecutive cases treated between July 1967 and January 1969 are as follows: 19 recovered and are alive at the time of writing $(49 \%), 8$ recovered from ventriculitis but died of other causes $(21 \%)$, and 12 died as a direct result of the ventriculitis $(30 \%)$.

We are glad to acknowledge the help of Roussel Laboratories (Mrs. P. Burke) and Beecham Research Laboratories for estimation of drug levels, and Mrs. Chester for the bacteriological data. The surgical treatment of the children was under Mr. R. B. Zachary, Mr. J. Lister, and their team, and their daily care under house physicians Drs. K. W. Allen, J. Baildon, D. J. Collinge, M. Gibbs, R. Hague, and A. Zachary.

\section{REFERENCES}

Eckstein, H. B., Cooper, D. G. W., Howard, E. R., and Pike, Juliet (1967). Cause of death in children with meningomyelocele or hydrocephalus. Archives of Disease in Childhood, 42, 163.

Fosson, A. R., and Fine, R. N. (1968). Neonatal meningitis. Presentation and discussion of 21 cases. Clinical Pediatrics 7, 404.

Jasper, P. L., and Merrill, R. E. (1965). Hydrocephalus and myelomeningocele. Central nervous system infection. American fournal of Diseases of Children, 110, 652.

Knudsen, E. T., Brown, D. M., and Rolinson, G. N. (1962). A new orally effective penicillinase-stable penicillin-BRL. 1621 . Lancet, 2, 632.

Lorber, J. (1961). Systemic ventriculographic studies in infants born with meningomyelocele and encephalocele. The incidence and development of hydrocephalus. Archives of Disease in Childhood, 36, 381.

- (1967). Intrathecal and intraventricular kanamycin in the treatment of meningitis and ventriculitis in infants. Postgraduate Medical fournal, Suppl. (May), 52.

-, and Bruce, A. M. (1963). Prospective controlled studies in bacterial 'meningitis' in spina bifida cystica. Developmental Medicine and Child Neurology, 5, 146.

- - , and Pickering, D. (1966). Incidence and treatment of postmeningitic hydrocephalus in the newborn. Archives of Disease in Childhood, 41, 44.

- , and Segall, M. (1962). Bacterial meningitis in spina bifida cystica. A review of 37 cases. Archives of Disease in Childhood, 37, 300 .

Newman, R. L., and Holt, R. J. (1967). Intrathecal gentamicin in treatment of ventriculitis in children. British Medical fournal, $1,539$.

Sharrard, W. J. W., Zachary, R. B., Lorber, J., and Bruce, A. M. (1963). A controlled trial of immediate and delayed closure of spina bifida cystica. Archives of Disease in Childhood, 38, 18.

Stark, G. (1968). Treatment of ventriculitis in hydrocephalic infants: intrathecal and intraventricular use of the new penicillins. Developmental Medicine and Child Neurology, 15, 36.

\section{Appendix}

Determination of gentamicin CSF levels. The method used to estimate the gentamicin content of serum is a turbidimetric assay. The test organism is Staphylococcus aureus ATCC $6538 \mathrm{P}^{\star}$. The organism is maintained on Penassay seed agar.

(1) Transfer the test organism to a fresh tube of Difco Penassay broth and incubate overnight at $37^{\circ} \mathrm{C}$.

(2) Make a 1/1000 dilution of this overnight culture to be used as the inoculum.

(3) Set up a series of $\mathbf{8}$ serological test-tubes containing $2.0 \mathrm{ml}$. sterile Penassay broth per tube and label the series of tubes 1 to 8 .

(4) Add aseptically to tube No. $1,2.0 \mathrm{ml}$. test serum and mix thoroughly.

(5) Remove $2.0 \mathrm{ml}$. from tube No. 1 and add to tube No. 2.

(6) Mix thoroughly and repeat this procedure of transferring $2.0 \mathrm{ml}$. from one tube to the next through to tube No. 8.

(7) Remove $2.0 \mathrm{ml}$. from tube No. 8 and discard it giving a final volume in each tube of $2.0 \mathrm{ml}$.

(8) Inoculate each tube with $0.1 \mathrm{ml}$. previously described inoculum. Incubate all tubes for 24 hours at $37^{\circ} \mathrm{C}$.

An estimation of gentamicin CSF level may be obtained from the following Table.

TABLE

\begin{tabular}{|c|c|c|c|c|c|c|c|c|c|}
\hline \multirow{2}{*}{ Pattern } & \multicolumn{8}{|c|}{ Tube No. } & \multirow{2}{*}{$\mu \mathrm{g} . / \mathrm{ml}}$. \\
\hline & 1 & 2 & 3 & 4 & 5 & 6 & 7 & 8 & \\
\hline $\begin{array}{l}\text { A } \\
\text { B } \\
\text { C } \\
\text { D } \\
\mathbf{E}\end{array}$ & $\begin{array}{l}- \\
- \\
- \\
-\end{array}$ & $\begin{array}{l}- \\
\overline{-} \\
-\end{array}$ & $\begin{array}{l} \pm \\
- \\
- \\
-\end{array}$ & $\begin{array}{l}+ \\
\pm \\
- \\
- \\
-\end{array}$ & $\begin{array}{l}+ \\
+ \\
\pm \\
- \\
-\end{array}$ & $\begin{array}{l}+ \\
+ \\
+ \\
\pm \\
-\end{array}$ & $\begin{array}{l}+ \\
+ \\
+ \\
+ \\
\pm\end{array}$ & $\begin{array}{l}+ \\
+ \\
+ \\
+ \\
+\end{array}$ & $\begin{array}{r}1 \cdot 0 \\
2 \cdot 0 \\
4 \cdot 0 \\
8 \cdot 0 \\
16 \cdot 0\end{array}$ \\
\hline
\end{tabular}

+ Turbid; \pm Slightly turbid; - Clear.

Determination of cloxacillin CSF levels. The method used for estimation of CSF levels of cloxacillin is similar to that for other penicillins.

$$
\star \text { British equivalent } \frac{\text { Staph. aureus }}{\text { NCTC } 7447}
$$

\section{Addendum}

A 2-year-old child with spina bifida had a Holter valve inserted when 6 weeks old. Investigations 18 months later for an intermittent pyrexia revealed a Staph. albus septicaemia. Systemic penicillin did not eradicate the infection until the colonized valve system was removed.

Two weeks after operation, she became unwell, and from the ventricular CSF and from an accumulation of fluid beneath a scalp flap, Pseudomonas pyocyaneus was grown. Daily ventricular taps were performed for 10 days to instil $10 \mathrm{mg}$. gentamicin, and systemic gentamicin was continued for 3 weeks. The intracranial pressure was controlled by acetazolamide. She made a complete recovery and her intellect was not affected.

Correspondence to Dr. J. Lorber, The Children's Hospital, Western Bank, Sheffield 10. 